\title{
ZNACZENIE „PROCESU LEKARZY” PRZED AMERYKAŃSKIM TrybunAŁEM WoJSKOWYM NR 1 W NORYMBERDZE DLA PRAWNOKARNEJ OCENY EKSPERYMENTÓW BADAWCZYCH
}

\section{Wstęp}

Chociaż wykorzystywanie człowieka do celów badawczych było zjawiskiem niechlubnie towarzyszącym rozwojowi medycyny od zarania dziejów, a szczególnie od połowy XIX w. ${ }^{1}$, to eksperymenty na więźniach obozów koncentracyjnych III Rzeszy wykroczyły ponad wszelkie dotychczasowe nadużycia pod względem liczby ofiar i sprawców, a także okrucieństwa tych ostatnich ${ }^{2}$. Ich powojenne rozliczenie nastąpiło na kilku ścieżkach. W postępowaniu przed Międzynarodowym Trybunałem Wojskowym w Norymberdze (dalej: MTW) w sprawie głównych niemieckich przestępców wojennych, zakończonym wyrokiem z 30 września i 1 października 1946 r., kwestia eksperymentów na więźniach pojawiła się epizodycznie, co wynikało z ukierunkowania procesu na całościową ocenę zbrodniczej działalności III Rzeszy³. Całokształt tych

* Dr, Katedra Prawa Karnego, Wydział Prawa, Prawa Kanonicznego i Administracji, Katolicki Uniwersytet Lubelski Jana Pawła II, e-mail: mkinga@kul.pl, https:/ /orcid.org/ 0000-0002-9433-4356.

1 Zob. np. G. Chamayou, Podte ciała. Eksperymenty na ludziach w XVIII i XIX wieku, tłum. J. Bodzińska, K. Thiel-Jańczuk, Gdańsk 2012, passim.

2 Zob. S. Sterkowicz, Nieludzka medycyna. Lekarze w stużbie nazizmu, Warszawa 2007, s. 14-20, 117-118; J.D. Moreno, Undue risk. Secret State Experiments on Humans, New York 1999, s. 54, 59-60, 71; A. Mitscherlich, F. Mielke, Nieludzka medycyna. Dokumenty procesu norymberskiego przeciwko lekarzom, tłum. A. Bukowczyk, Warszawa 1963, s. 272-273.

3 Zob. art. VI Karty Międzynarodowego Trybunału Wojskowego z dnia 8 sierpnia 1945 r. (Porozumienie międzynarodowe w przedmiocie ścigania i karania głównych 
eksperymentów był natomiast przedmiotem sprawy Stany Zjednoczone Ameryki przeciwko Karlowi Brandtowi i innym, znanej jako „proces lekarzy", rozpoznawanej przez Amerykański Trybunał Wojskowy nr 1 w Norymberdze (dalej: ATW nr 1) od października 1946 r. i zakończonej wyrokiem z 19 i 20 sierpnia 1947 r. ${ }^{4}$ Proces ten miał już inny charakter prawny ze względu na to, że nie był prowadzony przez sąd międzynarodowy ${ }^{5}$. Spośród 23 oskarżonych za czyny związane z eksperymentami medycznymi skazanych zostało 15, w tym 12 lekarzy. W większości byli to główni decydenci odpowiedzialni za medyczne zbrodnie III Rzeszy. Spośród ok. 200 lekarzy zaangażowanych w eksperymenty objęte sprawą ${ }^{6}$ oskarżono w niej tylko kilku bezpośrednich wykonawców. Pozostali byli sądzeni w odrębnych procesach, głównie prowadzonych przez poszczególne państwa ${ }^{7}$.

przestępców wojennych Osi Europejskiej, podpisane w Londynie 8 sierpnia 1945 r., Dz. U. z 1947 r. Nr 63, poz. 367, dalej: Karta MTW); Judgment, w: Trial of the Major War Criminals before the International Military Tribunal, Nuremberg, 14 November 1945 - 1 October 1946, t. 1, Nuremberg 1947, ss. 171-341 (dalej: wyrok MTW), s. 226, 228, 231, 252, 269, 271.

4 Tekst wyroku w: Trials of War Criminals before the Nuernberg Military Tribunals, t. 2: "The Medical Case", Nuernberg 1946-1949 (dalej: Trials II), s. 171-300, dalej: wyrok ATW nr 1.

5 ATW nr 1 został powołany na podstawie ustawy Sojuszniczej Rady Kontroli Niemiec (Control Council Law No 10. Punishment of persons guilty of war crimes, crimes against peace and against humanity, w: Trials of War Criminals before the Nuernberg Military Tribunals, t. 1: "The Medical Case”, Nuernberg 1946-1949, (dalej: Trials I, s. XVI-XIX, dalej: ustawa nr 10) przez Gubernatora Wojskowego dla Niemiec w strefie okupacyjnej administrowanej przez Stany Zjednoczone (zob. Order Constituting Tribunal I, Office of Military Government for Germany (U. S.), APO 742, General Orders No 68, 26 October 1946, w: Trials I, s. 5). Mimo to dostrzega się w "procesie lekarzy” pewne cechy procesu międzynarodowego. Świadczyć ma o tym sui generis ponadnarodowy charakter wspomnianej ustawy i odmowa przyjęcia apelacji przez Sąd Najwyższy USA, zob. G.J. Annas, L.H. Glantz, B.F. Katz, Informed Consent to Human Experimentation: The Subject's Dilemma, Cambridge, Massachusetts 1977, s. 7-8; M.C. Bassiouni, T.G. Baffes, J.T. Evrard, An Appraisal of Human Experimentation in International Law and Practice: the Need for International Regulation of Human Experimentation, Journal Criminal Law and Criminology 1981, t. 72, nr 4, s. 1640.

6 Zob. T. Cyprian, J. Sawicki, Nieznana Norymberga. Dwanaście procesów norymberskich, Warszawa 1965, s. 26.

7 Szerzej zob. np. S. Sterkowicz, Lekarze-mordercy spod znaku swastyki, Torun 1999, s. 165, 202, 204-205, 224-226, 232, 302. Mimo to wielu sprawców skutecznie ukryło się przed wymiarem sprawiedliwości (zob. tamże, s. 100-119, 153-157; R.J. Lifton, Ärzte im Dritten Reich, tłum. A. Lösch i in., Stuttgart 1988, s. 326-327; J.D. Moreno, Undue..., s. 89-102. 
Wyrok ATW nr 1 znany jest przede wszystkim jako źródło tzw. Kodeksu norymberskiego, wciąż uznawanego symbolicznie za uniwersalny dekalog eksperymentowania na człowieku' ${ }^{8}$. Niniejsze opracowanie koncentruje się jednak na poszukiwaniu nowej wartości wniesionej przez tenże wyrok i poprzedzający go proces nie tyle do szeroko rozumianych standardów prawnomedycznych, co - ściślej - do ocen prawnokarnych. Przed „procesem lekarzy” utrwaliło się przekonanie, że eksperyment medyczny może być zakwalifikowany jako przestępstwo przeciwko zdrowiu lub życiu w razie spowodowania odpowiednio poważnych skutków oraz naruszenia reguł jego dopuszczalności, wywodzonych z deontologii lekarskiej lub ogólnych zasad prawa i niekiedy kodyfikowanych w aktach administracyjnych9. Praktyka wymiaru sprawiedliwości była jednak w tym obszarze znikoma, a kwestia prawnych granic udziału człowieka w eksperymencie badawczym napotykała na rozbieżne oceny ${ }^{10}$. „Proces lekarzy" miał za przedmiot eksperymenty, których bezprawny charakter nie budził wątpliwości. Analizując kończący go wyrok, należy zatem ustalić po pierwsze, na ile przyjęta w nim kwalifikacja prawna stanowiła kontynuację dotychczasowego podejścia, a na ile był to nowy kierunek

8 Kodeksem norymberskim nazywany jest fragment wyroku ATW nr 1, określający 10 zasad dopuszczalności eksperymentu medycznego z udziałem człowieka. Upatruje się w nim pierwszy katalog przesłanek dopuszczalności eksperymentu medycznego o charakterze ponadnarodowym. Do jego treści nawiązywano w późniejszych międzynarodowych standardach medycznych i kodyfikacjach deontologicznych (zob. np. art. 7 Międzynarodowego Paktu Praw Obywatelskich i Politycznych, United Nation Treaty Series (dalej: UNTS) 1983, t. 999, s. 171, Dz. U. z 1977 r. Nr 38, poz. 167; World Medical Association, Declaration of Helsinki Ethical Principles for Medical Research Involving Human Subjects, Journal of the American Medical Association 2013, nr 20; M.C. Bassiouni, T. Baffes, J.T. Evrard, Le contrôle international de l'expérimentation sur l'homme, Revue Internationale de Droit Pénal 1980, nr 3-4, s. 323, 325, 327; P. Amiel, Des cobayes et des hommes. Expérimentation sur l'être humain et justice, Paris 2011, s. 10, 14-15, 19, 78; E. Shuster, Fifty years later: the significance of the Nuremberg Code, The New English Journal of Medicine 1997, t. 337, nr 20, s. 1436, 1439; Y. Ternon, Genèse et sens du Code du Nuremberg, w: De Nuremberg à la loi Huriet. Essais thérapeutiques et recherche médicale, red. S. Abtroun, Paris 2001, s. 91, 105).

9 Zob. np. Wyrok Trybunału Poprawczego w Lyonie z dnia 15 grudnia 1859 r. dotyczący odpowiedzialności karnej za eksperyment medyczny, tłum. M. Gałązka, Studia Prawnicze KUL 2015, nr 3, s. 91-95; L. von Bar, Medizinische Forschung und Strafrecht, w: Recht und Medizin, Hrsg. A. Eser, A. Künschner, Darmstadt 1990, s. 65-84; C. Stooss, Chirurgische Operation und ärztliche Behandlung, Berlin 1898, s. 77-89; P. Amiel, Des cobayes..., s. 49.

10 Szerzej zob. M. Gałązka, Prawnokarne granice nowatorskiej interwencji medycznej, Lublin 2019, s. $129 \mathrm{i}$ nn. 
ocen, oraz po drugie - czy i jak określono w nim granice, po przekroczeniu których eksperyment badawczy może być podstawą odpowiedzialności karnej, oraz jakie znaczenie miały one dla ówczesnych i późniejszych ocen prawnokarnych. Przedmiot "procesu lekarzy” i treść kończącego go wyroku nakazuje zarazem odnieść się nie tyle do prawa konkretnego państwa lub państw, co raczej do ogólnych założeń wspólnych współczesnym systemom prawa karnego ze szczególnym uwzględnieniem kontekstu międzynarodowego prawa karnego. Znaczenie tego ostatniego kontekstu ujawnia się zwłaszcza w perspektywie recepcji wyroku ATW nr 1 do ponorymberskiego prawa humanitarnego.

\section{Zakres przedmiotowy "procesu lekarzy"}

Eksperymenty medyczne nie stanowiły wyłącznego przedmiotu "procesu lekarzy”, ale dominowały wśród innych zarzutów. Akt oskarżenia zarzucał wszystkim oskarżonym, że od września 1939 r. do kwietnia 1945 r.

byli głównymi sprawcami, uczestnikami, rozkazywali, pomagali, brali świadomy udział i pozostawali w związku z planami i przedsięwzięciami, które obejmowały eksperymenty medyczne [...] bez zgody uczestników, w toku których to eksperymentów oskarżeni popełnili morderstwa, czyny bestialskie, okrutne, tortury i inne nieludzkie czyny ${ }^{11}$.

Były to przedsięwzięcia ukierunkowane na cele poznawcze, w większości objęte programami kierowanymi odgórnie, obliczone na realizację celów militarnych, zwalczanie chorób zakaźnych lub wdrożenie ideologii rasistowsko-eksterminacyjnej. Fakt ich przeprowadzania nie został w wyroku zakwestionowany, podobnie jak ich przebieg, skutki i brak lub wadliwość zgody uczestników ${ }^{12}$. Ustalenia faktyczne ATW nr 1 są jednak niekiedy stosunkowo ogólne lub fragmentaryczne, co wynikało w dużej mierze z ograniczenia ich do ustaleń minimalnych, wystarczających do orzeczenia o winie i karze konkretnych osób.

11 Indictment, pkt. 7-9, w: Trials I..., s. 14-15.

12 Część uniewinniająca wyroku w przeważającym zakresie wynikała z braku dowodów wskazujących na winę konkretnych oskarżonych, zob. wyrok ATW nr 1, s. 208-210, 228-235, 248-253, 272-277, 285-286, 292-295. 
Wśród eksperymentów służących celom militarnym przedmiotem procesu były po pierwsze badania w obozie koncentracyjnym Dachau nad możliwościami ratowania zestrzelonych lotników. Obejmowały eksperymenty wysokościowe, polegające na umieszczaniu ludzi w komorze niskiego ciśnienia aż do momentu zgonu lub utraty przytomności, w wyniku których zmarło ok. 70-80 osób ${ }^{13}$, eksperymenty termiczne, polegające na zanurzaniu uczestników w lodowatej wodzie lub na pozostawianiu nago na mrozie, które spowodowały co najmniej 70 zgonów ${ }^{14}$, oraz eksperymenty nad skutkami spożywania wody morskiej, w których testowano preparaty mające ją uzdatnić, pozbawiając uczestników na 10 dni dostępu do wody słodkiej ${ }^{15}$. Celom militarnym służyły również eksperymenty polegające na ekspozycji więźniów obozu koncentracyjnego w Sachsenhausen i Natzweiler na działanie iperytu, które doprowadziły do zgonu co najmniej 50 osób $^{16}$, oraz testowanie akonityny dodanej do pocisków, którymi zastrzelono 5 więźniów obozu w Sachsenhausen ${ }^{17}$. Postępowanie przed ATW nr 1 obejmowało też eksperymenty mające usprawnić leczenie ran u żołnierzy niemieckich, prowadzone na polskich więźniarkach obozu koncentracyjnego w Ravensbrück, nie tylko bez ich zgody, ale i wbrew sprzeciwom. Polegały one na wytwarzaniu ran, zanieczyszczaniu ich i zakażaniu bakteriami w celu oceny skuteczności sulfanilamidów, operacyjnym łamaniu kości oraz wycinaniu części kości, mięśni i nerwów,

13 Eksperymenty te były prowadzone głównie przez Sigmudna Raschera, który jeszcze podczas wojny został rozstrzelany przez hitlerowców, toteż przed ATW nr 1 odpowiadali w tym zakresie jego zwierzchnicy. Podobne, choć mniej drastyczne eksperymenty prowadzili Hans W. Romberg i Siegfried Ruff, którzy zostali uniewinnieni przez ATW nr 1, zob. wyrok ATW nr 1, s. 237, 272-276; S. Sterkowicz, Nieludzka medycyna. Lekarze..., s. 159-167; A. Mitscherlich, F. Mielke, Nieludzka medycyna. Dokumenty..., s. 2-36.

14 Eksperymenty te prowadził głównie S. Rascher, przed ATW nr 1 zaś odpowiadali jego zwierzchnicy, zob. wyrok ATW nr 1, s. 200-201, 237; S. Sterkowicz, Nieludzka medycyna. Lekarze..., s. 167-173; A. Mitscherlich, F. Mielke, Nieludzka medycyna. Dokumenty..., s. $39-42,48,52-53$.

15 Eksperymenty te prowadził Wilhelm Beigelböck z inicjatywy Hermana Becker-Freysenga i Oskara Schrödera, wszyscy skazani przez ATW nr 1, zob. wyrok ATW nr 1, s. 213-217, 285, 292; S. Sterkowicz, Nieludzka medycyna. Lekarze..., s. 174-177. A. Mitscherlich, F. Mielke, Nieludzka medycyna. Dokumenty..., s. 60-80.

16 Zob. wyrok ATW nr 1, s. 194; S. Sterkowicz, Nieludzka medycyna. Lekarze..., s. 183-187, A. Mitscherlich, F. Mielke, Nieludzka medycyna. Dokumenty..., s. 165-170.

17 Przeprowadził ją m.in. Joachim Mrugowsky - skazany przez ATW nr 1, zob. wyrok ATW nr 1, s. 245-246; S. Sterkowicz, Nieludzka medycyna. Lekarze..., s. 178-179. 
powodując ciężkie nieleczone powikłania, trwałe kalectwo u wielu ofiar i śmierć $5 \mathrm{z}$ nich ${ }^{18}$. Wśród eksperymentów dotyczących chorób zakaźnych przedmiotem „procesu lekarzy” były m.in. testowanie szczepionek przeciwko durowi plamistemu na więźniach obozu koncentracyjnego w Buchenwaldzie, których zakażano bakteriami duru po podaniu badanych szczepionek lub przydzieleniu do nieszczepionej grupy kontrolnej, co doprowadziło do śmierci co najmniej kilkudziesięciu osób ${ }^{19}$, i eksperymenty nad szczepionką przeciwko malarii w obozie koncentracyjnym w Dachau, obejmujące zakażanie więźniów tą chorobą, co doprowadziło do 300-400 zgonów ${ }^{20}$. Cel eksterminacyjny realizowany był w ramach eksperymentów nad sterylizacją, prowadzonych w Oświęcimiu i Ravensbrück, które polegały na naświetlaniu promieniami Roentgena gruczołów płciowych i usuwaniu ich do badań histopatologicznych lub na wstrzykiwaniu płynu drażniącego do jamy macicy, co powodowało niepłodność lub obrażenia na ciele ${ }^{21}$. Omawiany proces obejmował również zamordowanie 112 więźniów obozu koncentracyjnego w Oświęcimiu w celu skompletowania zbioru "szkieletów żydowskich” dla Uniwersytetu Rzeszy w Strasburgu 22 .

18 Zob. wyrok ATW nr 1, s. 201, 223-225; W. Półtawska, Operacje doświadczalne w obozie koncentracyjnym Ravensbrück, w: Okupacja i medycyna. Drugi wybór artykułów z „Przeglądu Lekarskiego - Oświęcim” z lat 1961-1973, wybór zespół red. „Przeglądu Lekarskiego - Oświęcim", Warszawa 1975, s. 82, 85-88; S. Sterkowicz, Nieludzka medycyna. Lekarze..., s. 148-158, 212-214; A. Mitscherlich, F. Mielke, Nieludzka medycyna. Dokumenty..., s. 126-137, 151-152. Eksperymenty te prowadzili: Karl Gebhardt, Fritz Fischer i Herta Oberhäuser - wszyscy troje skazani przez ATW nr 1.

19 Eksperymenty te były prowadzone m.in. przez skazanych w omawianym procesie J. Mrugowsky'ego i Gerhard Rose, zob. wyrok ATW nr 1, s. 219-222, 244; S. Sterkowicz, Nieludzka medycyna. Lekarze..., s. 119-127; A. Mitscherlich, F. Mielke, Nieludzka medycyna. Dokumenty..., s. 84-106, 110.

20 Zob. wyrok ATW nr 1, s. 264-266; S. Sterkowicz, Nieludzka medycyna. Lekarze..., s. $142-144$.

${ }^{21}$ Zob. wyrok ATW nr 1, s. 238-239, 278-279; S. Sterkowicz, Nieludzka medycyna. Lekarze..., s. 193-200; A. Mitscherlich, F. Mielke, Nieludzka medycyna. Dokumenty..., s. 247-256; R.J. Lifton, Ärzte..., s. 309-317, 319-326.

22 Zob. wyrok ATW nr 1, s. 239-240; A. Mitscherlich, F. Mielke, Nieludzka medycyna. Dokumenty..., s. 174-183; S. Sterkowicz, Nieludzka medycyna. Lekarze..., s. 204-208. 


\section{Ocena prawna}

Zakres jurysdykcji ATW nr 1 wytyczony został wspomnianą już ustawą nr 10 Sojuszniczej Rady Kontroli Niemiec. Ten sam akt prawny określał materialnoprawne podstawy oceny czynów zarzuconych oskarżonym. Dokonując tej oceny, ATW nr 1 uznał eksperymenty wskazane w zarzutach za zbrodnie wojenne i zbrodnie przeciwko ludzkości, opierając się na art. II ust. 1 lit. b i c ustawy nr $10^{23}$. W powołanych przepisach zbrodnie wojenne określono jako

okrucieństwa lub przestępstwa przeciwko osobom lub mieniu, które naruszają prawa lub zwyczaje wojenne i obejmują: morderstwo, złe traktowanie, deportację do pracy niewolniczej albo w innym celu ludności cywilnej z okupowanego terytorium, morderstwo lub złe traktowanie jeńców wojennych lub osób na morzu, zabijanie zakładników, grabież własności publicznej lub prywatnej, bezmyślne burzenie miast lub wsi lub spustoszenia nieusprawiedliwione koniecznością wojenną, ale nie ograniczają się do wymienionych czynów,

\section{a zbrodnie przeciwko ludzkości - jako}

okrucieństwa i przestępstwa, które obejmują morderstwo, eksterminację, obracanie ludzi w niewolników, deportację, więzienie, torturowanie, zgwałcenie albo inne nieludzkie czyny popełnione przeciwko jakiejkolwiek ludności cywilnej lub prześladowania ze względów politycznych, rasowych lub religijnych, niezależnie od tego, czy naruszało to prawo kraju, w którym zostało popełnione, ale nie ograniczają się do wymienionych czynów.

Przepisy te były wzorowane na opisach zbrodni wojennych i zbrodni przeciwko ludzkości z art. VI lit. b i c Karty MTW24, a zastosowanie ich przez ATW nr 1 do eksperymentów hitlerowskich powtarzało ocenę wyrażoną przez $\mathrm{MTW}^{25}$. W kwestii rozróżnienia wśród eksperymentów objętych „procesem lekarzy” zbrodni wojennych i zbrodni przeciwko ludzkości ATW nr 1 zaznaczył, że te pierwsze popełnione zostały

${ }^{23}$ Zob. wyrok ATW nr 1, s. 181.

${ }^{24}$ Zob. J. Maogoto, The Work of National Military Tribunals under Council Control Law 10, w: The Legal Regime of the International Criminal Court: Essays in Honour of Professor Igor Blishchenko, red. J. Doria, H.P. Gasser, M.C. Bassiouni, Leiden-Boston 2009, s. 51-52; I. Fouchard, w: M. Delmas-Marty i in., Le crime contre l'humanité, Paris 2018, s. 12-13.

${ }^{25}$ Zob. wyrok MTW, s. 254-255. 
na osobach cywilnych i członkach sił zbrojnych narodów, które w owym czasie znajdowały się w stanie wojny z Rzeszą Niemiecką [...] w wykonywaniu swego prawa kontroli jako mocarstwo prowadzące wojnę", a te drugie - na „niemieckich osobach cywilnych i obywatelach innych krajów ${ }^{26}$.

Nowe, niestosowane dotąd podejście do kwalifikacji prawnej bezprawnego eksperymentu medycznego wynikało z bezprecedensowej skali i stopnia dotkliwości wykorzystywania ludzi do celów badawczych, jakiego dopuścili się oskarżeni. Wpisywało się zarazem w kontekst nieznanego w dotychczasowej historii zasięgu ścigania przestępstw popełnionych w ramach konfliktu zbrojnego.

Treść wyroku ATW nr 1 wskazuje na to, że ustawa nr 10 nie była wyłączną podstawą kwalifikacji prawnej eksperymentów objętych omawianym procesem. Trybunał stwierdził bowiem w ślad za aktem oskarżenia ${ }^{27}$ :

jest zupełnie oczywiste, że wszystkie te eksperymenty z ich bestialstwem, torturami, powodowaniem kalectwa i śmierci były przeprowadzane z całkowitą pogardą dla umów międzynarodowych, praw i zwyczajów wojennych, ogólnych zasad prawa karnego, wynikających z ustaw karnych wszystkich cywilizowanych narodów i z ustawy nr 10 Rady Kontrolnej. Eksperymenty na ludziach przeprowadzone $\mathrm{w}$ tych warunkach są ewidentnie sprzeczne $\mathrm{z}$ „zasadami prawa narodów, jakie wynikają z obyczajów przyjętych wśród ludów cywilizowanych, z praw ludzkości i nakazów sumienia publicznego"28.

Wypowiedź ta sygnalizuje, że bezprawność rozpoznawanych czynów wynikała również z przednorymberskiego prawa międzynarodowego oraz z państwowego prawa karnego. Chociaż żadnego z tych wątków ATW nr 1 nie rozwinął, to niewątpliwie przyjąć można, że podzielał stanowisko MTW w kwestii prawnomiędzynarodowego umocowania odpowiedzialności karnej za zbrodnie wojenne oraz zbrodnie przeciwko ludzkości ${ }^{29}$. Nawiązanie do „ustaw karnych wszystkich cywilizowanych

26 Zob. wyrok ATW nr 1, s. 174, 198, 207, 217, 222, 227, 240, 248, 271, 285, 290, 292.

27 Zob. Indictment..., pkt. 10 i 15, s. 15-16, 17.

28 Wyrok ATW nr 1, s. 183.

29 Nt. znaczenia procesu przed MTW dla późniejszych 12 procesów prowadzonych przez amerykańskie trybunały wojskowe zob. też W. Kulesza, Crimen laesae iustitiae. Odpowiedzialność karna sędziów i prokuratorów za zbrodnie sądowe wedtug prawa norymberskiego, niemieckiego, austriackiego i polskiego, Łódź 2013, s. 23. W ślad za oceną prawną dokonaną przez MTW warto podkreślić, że zachowania objęte definicją zbrodni wojennych w art. VI lit. b Karty MTW i art. II ust. 1 lit. b ustawy nr 10 naruszały przepisy art. 46, 50, 52 i 56 konwencji 
narodów" wydaje się mieć natomiast charakter jedynie subsydiarny. Nie ulega wątpliwości, że czyny objęte wyrokiem ATW nr 1 były zarazem przestępstwami przeciwko życiu i zdrowiu znanymi kodeksom karnym, chociaż charakteryzowały się ponadto szczególną cechą, trudną do wyrażenia za pomocą ówczesnych konstrukcji karnistycznych, w postaci masowej skali, na jaką je popełniano, oraz wykorzystania ofiar konfliktu zbrojnego i ukierunkowania na realizację celów militarnych ${ }^{30}$. Okoliczności te przesądziły o zastosowaniu kwalifikacji prawnej wywiedzionej z prawa międzynarodowego. W szczególności ATW nr 1 w żadnym miejscu oceny prawnej nie odniósł się do niemieckiego kodeksu karnego ${ }^{31}$.

Do czynności sprawczych obydwu typów zbrodni Trybunał nawiązał bezpośrednio tylko w odniesieniu do kilku oskarżonych, stwierdzając wówczas, że eksperymenty przypisane konkretnemu oskarżonemu łączyły się ze skutkami śmiertelnymi, najczęściej określonymi jako morderstwa, czyny bestialskie, okrutne, tortury i inne nieludzkie czyny ${ }^{32}$. W sposób ogólny zaznaczył natomiast, że podczas każdego eksperymentu uczestnicy doznawali „wielkiego bólu lub tortur”, w wyniku większości z nich odnieśli trwałe obrażenia, okaleczenia albo ponieśli śmierć, będącą bezpośrednim skutkiem eksperymentów albo braku dostatecznej opieki medycznej później3. Warto tu zauważyć, że ATW nr 1 nie warunkował przyjętej kwalifikacji prawnej wymiernością skutków eksperymentu w postaci śmierci lub uszczerbku na zdrowiu. Jak wynika z ustaleń dotyczących eksperymentów z wodą morską, za wystarczające uznawał brutalne

haskiej z 18 października 1907 r. o prawach i zwyczajach wojny lądowej i w art. 2-4 i art. 46 konwencji genewskiej z 27 lipca 1929 r. o jeńcach wojennych (zob. wyrok MTW, s. 253). Zbrodnie przeciwko ludzkości były nową konstrukcją prawną (zob. J.-P. Bazelaire, T. Cretin, La justice pénale internationale, Paris 2000, s. 73; I. Fouchard, w: M. Delmas-Marty i in., Le crime..., s. 10-12), chociaż w zakresie czynności sprawczych wykazywały podobieństwo do zbrodni wojennych oraz przestępstw pospolitych przewidzianych w ustawodawstwach państwowych.

30 Zob. W. Wolter, Wstęp, w: Wyrok Amerykańskiego Trybunatu Wojskowego, Biuletyn Głównej Komisji Badania Zbrodni Hitlerowskich w Polsce 1970, t. 20, s. 33.

31 Zob. H.-M. Sass, Ambiguities In Judging Cruel Human Experimentation: Arbitrary American Responses to German and Japanese Experiments, Eubios Journal of Asian and International Bioethics 2003, nr 13, s. 102-104. Podobnie w wyroku z 4 grudnia 1947 r. Amerykańskiego Trybunału Wojskowego w tzw. procesie prawników, zob. W. Kulesza, Crimen..., s. 22.

32 Zob. np. wyrok ATW nr 1, s. 207, 216-217, 222, 227, 240, 247-248, 271.

33 Zob. tamże, s. 183. 
traktowanie uczestników i doznawane przez nich cierpienie ${ }^{34}$. Obok konstrukcji zbrodni wojennych i zbrodni przeciwko ludzkości o prawnokarnej ocenie czynów objętych "procesem lekarzy" zadecydowało naruszenie zasad dopuszczalności eksperymentu medycznego. $Z$ niewiadomych powodów w wyroku nie odniesiono się jednak do treści Wytycznych dla nowych terapii i podejmowania eksperymentów na istotach ludzkich Ministra Spraw Wewnętrznych Rzeszy z 1931 r. ${ }^{35}$, które takie właśnie zasady przewidywały oraz - co warte podkreślenia - nie zostały uchylone w czasach III Rzeszy i pozostały w mocy aż do 1948 r. ${ }^{36}$ ATW nr 1 zdecydował się zrekonstruować je bezpośrednio z etyki lekarskiej, której stan ustalił z pomocą opinii biegłych, formułując 10 zasad, dla których przyjęło się określenie „Kodeks norymberski" ${ }^{37}$. Trybunał zaznaczył, że nie wszystkie z nich "są czysto prawniczej natury", stwierdzając, że kierował się zasadami, które ową naturę wykazują lub które przynajmniej pozostają w wyraźnym związku z kwestiami prawnymi ${ }^{38}$. Nie wyjaśnił jednak bliżej tych rozróżnień przypuszczalnie dlatego, że czyny zarzucone oskarżonym stanowiły na tyle oczywiste naruszenie prawa międzynarodowego i prawnokarnych zakazów chroniących życie i zdrowie, że zbędna była ich szczegółowa ocena pod kątem wszystkich przesłanek legalności eksperymentu medycznego ${ }^{39}$.

34 Zob. tamże, s. 292.

35 Richtlinien für neuartige Heilbehandlung und für die Vornahme wissenschaflicher Versuche am Menschen, Deutsche Medizinische Wochenschrift 1931, t. 12, nr 57, s. 509 (dalej: Wytyczne z 1931 r.). Nawiązywał do nich biegły oskarżenia Andrew Ivy, wskazując na ich zbieżność z zasadami zawodu medycznego w cywilizowanym świecie i z zasadami przyjętymi przez American Medical Association, zob. Extracts from the testimony of prosecution expert witness dr. Andrew C. Ivy, w: Trials II, s. 83; Advisory Committee on Human Radiation Experiments, Final Report, October 1995, https://archive.org/details/advisorycommitte00unit, data dostępu 24 kwietnia 2020 r., s. 148.

36 Zob. R.B. Ghooi, The Nuremberg Code - A critique, Perspectives in Clinical Research 2011, nr 2, s. 72-75; H.-M. Sass, Ambiguities..., s. 102-104. W konsekwencji podstawy do skazania sprawców eksperymentów objętych „procesem lekarzy” dawał również niemiecki Kodeks karny z 1870 r., w ślad za stanowiskiem doktryny niemieckiej ukształtowanym na początku XX w. (zob. przyp. 9; H.-M. Sass, Ambiguities..., s. 102-104).

37 Dalej też KN. Zob. wyrok ATW nr 1, s. 181-182. Pełną treść w języku polskim zob. m.in. w: M. Gałązka, Prawnokarne..., s. 180-181. Warto tu nadmienić, że w Wytycznych z 1931 r. granice dopuszczalności eksperymentu medycznego były bardziej rygorystyczne w porównaniu z Kodeksem norymberskim, zob. H.-M. Sass, Ambiguities..., s. 102.

38 Zob. wyrok ATW nr 1, s. 182-183.

39 Tamże, s. 183. 
Centralne miejsce wśród zasad Kodeksu norymberskiego zajmuje zgoda uczestnika eksperymentu. W pkt 1 ATW nr 1 stwierdził bowiem, co następuje:

Dobrowolna zgoda uczestnika jest absolutnie niezbędna. Oznacza to, że uczestnik musi mieć prawną zdolność do udzielenia zgody, powinien być w sytuacji pozwalającej mu na dokonanie swobodnego wyboru, wolnego od siły, oszustwa, podstępu, przymusu, zwodzenia lub jakiejkolwiek innej formy presji lub wymuszenia oraz musi mieć wystarczającą wiedzę i zrozumienie podstaw danej materii, aby umożliwiło mu to podjęcie rozeznanej i świadomej decyzji. Ten ostatni element wymaga, aby przed przyjęciem oświadczenia o zgodzie uczestnika eksperymentu poinformować go o istocie, czasie trwania i celu eksperymentu, o metodzie i środkach, za pomocą których będzie prowadzony, o wszelkich niedogodnościach i niebezpieczeństwach, których należy się rozsądnie spodziewać, i o skutkach dla jego zdrowia lub osoby, jakie mogą wyniknąć z udziału w eksperymencie. Obowiązek upewnienia się w kwestii skuteczności zgody i odpowiedzialność za to spoczywa na każdym, kto inicjuje, kieruje lub przeprowadza eksperyment. Ten obowiązek i odpowiedzialność mają charakter osobisty, który nie może być przeniesiony na inną osobę ze skutkiem w postaci bezkarności ${ }^{40}$.

Z perspektywy prawnokarnego znaczenia tej okoliczności na uwage zasługują trzy istotne kwestie. Po pierwsze Kodeks norymberski odrzuca stanowisko, jakoby osoba bez fachowej wiedzy nie była w stanie podjąć skutecznej decyzji o poddaniu się eksperymentowi badawczemu ${ }^{41}$.

40 Zob. też pkt 9: „Podczas eksperymentu uczestnik powinien mieć możliwość jego zakończenia, jeśli znalazł się w fizycznym lub duchowym stanie, w którym kontynuowanie eksperymentu uznaje za niemożliwe".

41 Znaczenie tej tezy ujawnia jej konfrontacja z argumentacją obrony, zwłaszcza oskarżonego G. Rose, który podnosił, że zazwyczaj tylko decyzja lekarza o przeprowadzeniu eksperymentu na samym sobie ma charakter świadomy, a w większości pozostałych przypadków występuje wykorzystanie niewiedzy, lekkomyślności, trudności ekonomicznych lub innej przymusowej sytuacji uczestnika eksperymentu (zob. Final Statement of Defendant Rose, w: Trials II, s. 161; podobnie Extracts from the closing brief for defendant Karl Brandt, w: Trials I, s. 983-984). Argumentacja ta mogłaby prowadzić do skonstruowania dużo bardziej rygorystycznych granic eksperymentowania na człowieku, niż przyjął ATW $\mathrm{nr}$ 1, ale nie po to została zaprezentowana w procesie. Oskarżony G. Rose wywiódł z niej bowiem wniosek, że eksperymenty, do których nieetyczne jest korzystanie z ochotników, są dopuszczalne „tylko wówczas, jeśli suwerenna władza państwowa ustali osoby z kręgu takich ludzi, którzy swoimi czynami przeciwko społeczeństwu przekreślili swoje prawo do życia" (Za: A. Mitscherlich, F. Mielke, Nieludzka medycyna. Dokumenty..., s. 102). 
Po drugie wyrok ATW nr 1 zrównuje w ocenie prawnej brak zgody ze zgodą wadliwą, co szczególnie dostrzec można w stanowisku Trybunału wobec eksperymentów z durem plamistym w Buchenwaldzie. Mimo że w początkowej ich fazie więźniowie zgłaszali się do nich ochotniczo, wyrok wyraźnie stwierdza, że nie można tego uznać za skuteczną zgodę ze względu na brak poinformowania o planowanym zakażaniu wysoce niebezpiecznym wirusem i ryzyku śmierci ${ }^{42}$. Po trzecie zaś omawiany wyrok za niewystarczającą dla uchylenia bezprawności eksperymentu badawczego uznaje zarówno zgodę milczącą, jak i hipotetyczną. Treść Kodeksu norymberskiego nie daje przestrzeni na rozważania zaprezentowane przez obrońcę K. Gebhardta, który utrzymywał, że dla oceny skuteczności zgody jako okoliczności wyłączającej bezprawność czynu nie ma zbyt istotnego znaczenia to, czy uczestniczki eksperymentalnych operacji w Ravensbrück zadeklarowały ją wyraźnie, ponieważ jeśli tak nie było, to nie można wykluczyć, że - nie mając szans na uniknięcie w inny sposób wykonania kary śmierci - zgodziły się na udział w eksperymentach milcząco, a nawet przy założeniu braku zgody milczącej trudno powątpiewać co do tego, że udzieliłyby zgody, gdyby miały pełną świadomość swojej sytuacji, czyli tego, że były skazane na śmierć i że udział w eksperymentach stanowił dla nich jedyną możliwość uniknięcia egzekucji ${ }^{43}$. W ocenie ATW nr 1 eksperymentalne operacje w Ravensbrück zostały przeprowadzone bez zachowania warunku zgody ${ }^{44}$.

Niezależnie od postawionego w Kodeksie norymberskim wymogu naukowej poprawności eksperymentu i jego subsydiarności wobec innych metod badawczych ${ }^{45}$ przebieg postępowania dowodowego ukazał słabość poszukiwania podstaw dla eksperymentu badawczego $\mathrm{w}$ obronie

42 Zob. wyrok ATW nr 1, s. 244.

43 Zob. Extract from the final plea for defendant Gebhardt, w: Trials II, s. 52-54.

${ }_{44}$ Zob. wyrok ATW nr 1, s. 244.

45 „Eksperyment musi nadawać się do dostarczenia owocnych efektów dla dobra społeczeństwa, których nie da się osiągnąć innymi metodami lub środkami badawczymi i które nie są w swej istocie przypadkowe lub bezużyteczne” (pkt 2). „Eksperyment powinien być tak zaplanowany i oparty na wynikach eksperymentów na zwierzętach oraz na znajomości naturalnej historii choroby lub innego badanego problemu, że przewidywane rezultaty uzasadniają jego przeprowadzenie” (pkt 3). „Eksperyment powinien być przeprowadzany wyłącznie przez osoby wykwalifikowane naukowo. Od osób, które prowadzą eksperyment, należy wymagać najwyższego poziomu umiejętności i ostrożności we wszystkich jego stadiach" (pkt 8). Zob. też wyrok ATW nr 1, s. 183, gdzie stwierdzono, że $\mathrm{w}$ wielu wypadkach eksperymenty będące przedmiotem procesu były przeprowadzane 
koniecznej lub stanie wyższej konieczności. Obrona, opierając się na tezie o doniosłości celów realizowanych przez przedmiotowe eksperymenty ${ }^{46}$ lub wartości uzyskanych wyników ${ }^{47}$, sytuowała ich przeprowadzenie w ramach „konieczności państwowej” jako okoliczności mającej wyłączać bezprawność i prawa narodu do samoobrony lub do zachowania samego siebie, które miałoby pozwalać nawet na naruszenie prawa międzynarodowego. Przyświecało temu założenie, że stan wyższej konieczności ma zastosowanie do ratowania nie tylko dóbr indywidualnych, ale i zbiorowych $^{48}$, np. „żywotnych interesów państwa jako uczestnika wojny i jednostek dotkniętych wojną", dla których bezpośrednie niebezpieczeństwo upatrywano $\mathrm{w}$ infekcjach ran $\mathrm{u}$ tysięcy żołnierzy na froncie wschodnim, które uchylić miały eksperymentalne operacje na więźniarkach Ravensbruck $^{49}$, oraz że dopuszczalne jest poświęcenie grupy ludzi dla ratowania innej, większej grupy. Jak twierdził G. Rose w kontekście eksperymentów nad szczepionkami przeciwdurowymi,

bez tych eksperymentów szczepionki, które okazały się bezużyteczne, byłyby produkowane $\mathrm{w}$ wielkich ilościach, ponieważ mają one wszystkie wspólną cechę: ich produkcja jest dużo prostsza i tańsza niż produkcja szczepionek skutecznych. [...] Pozostawał jeden tylko wybór - poświęcenie ludzkiego życia osób wyznaczonych w tym celu albo pozostawienie sprawy samej sobie i narażenie życia niezliczonych ludzkich istot, których wybierałby nie Urząd Policji Kryminalnej Rzeszy, lecz ślepy $\operatorname{los}^{50}$.

przez osoby niewykwalifikowane, przypadkowo, bez wystarczającego uzasadnienia naukowego i „w oburzających warunkach fizycznych”.

46 Zob. Extract from the closing brief for defendant Gebhardt, w: Trials I, s. 364-366, 364; Final Statement of defendant Fischer, w: Trials II, s. 169-170; Extract from the final plea for defendant Schroeder, w: Trials I, s. 434-436, 435; Extract from the testimony of defendant Mrugowsky, w: Trials II, s. 66-67.

47 Zob. Extract from the final plea for defendant Beiglboeck, w: Trials II, s. 64; Extracts from the testimony of defendant Karl Brandt, w: Trials I, s. 973; Extracts from the testimony of defendant Rose, w: Trials II, s. 69.

48 Zob. Extracts from the final plea for defendant Mrugowsky, w: Trials I, s. 540-541; Extract from the final plea for defendant Gebhardt, w: Trials II, s. 7-10; A. Mitscherlich, F. Mielke, Nieludzka medycyna. Dokumenty..., s. 105-106.

49 Zob. Extract from the final plea for defendant Gebhardt, s. 5-6, 8-9.

50 Extracts from the testimony of defendant Rose, s. 70; podobnie zob. Extracts from the final plea for defendant Mrugowsky, s. 540, który uznawał za wystarczającą podstawę wyższej konieczności okoliczność, że 142 osoby, które wedle oskarżenia zmarły w wyniku 
Wobec tego podejścia oponowali biegli oskarżenia, podnosząc: „nie ma usprawiedliwienia dla zabicia pięciu osób po to, aby uratować życie pięciu tysięcy" ${ }^{11} \mathrm{i}$

pojęcie ludzkości jest bardzo niebezpieczne. Dla lekarza jest niebezpieczne najbardziej ze wszystkiego. Dla lekarza jednostka stoi ponad ludzkością, a w tych ostatnich latach jednostka niestety została bardzo mocno zdegradowana ${ }^{52}$.

Myśl ta w przyszłości zaowocuje zasadą prymatu istoty ludzkiej nad interesem zbiorowym, należącą do współczesnego kanonu międzynarodowych standardów biomedycznych. To właśnie Kodeks norymberski dał jej konkretne podstawy, uzależniając dopuszczalność eksperymentu badawczego - interwencji medycznej motywowanej dobrem ponadindywidualnym - od zgody uczestnika oraz pewnego progu ryzyka, którego przekroczenie jest bezwzględnie niedopuszczalne, chociaż nie został on określony jednoznacznie ${ }^{53}$.

ATW nr 1 nie uznał za podstawę wyłączenia bezprawności objętych sprawą eksperymentów tego, że ich uczestnicy zostali wcześniej skazani na śmierć, co wyraźnie stwierdził w kontekście eksperymentu z zatrutymi pociskami:

eksperymentów z durem w Buchenwaldzie, to tylko 1\% osób, które umierały dziennie w zimie 1941-1942 na tę chorobę w jednej ze stref obozu.

51 Extracts from the testimony of prosecution expert witness dr. Andrew C. Ivy, w: Trials II, s. 42 .

52 Extracts from the testimony of prosecution witness professor Werner Leibbrandt, w: Trials II, s. 81.

53 Z pkt. 7 („Należy podjąć właściwe przygotowania i adekwatne środki dla ochrony uczestnika eksperymentu przed nawet najmniejszą możliwością uszczerbku, kalectwa lub śmierci”) i 10 („Badacz prowadzący eksperyment musi być przygotowany na zakończenie go w jakimkolwiek stadium, jeśli w wymaganej od niego dobrej wierze, przy wysokich umiejętnościach i starannym osądzie, ma podstawy przypuszczać, że kontynuowanie eksperymentu może doprowadzić do uszczerbku na zdrowiu, kalectwa lub śmierci uczestnika") KN wynikała niedopuszczalność przewidywanego zagrożenia dla zdrowia uczestnika eksperymentu, ale już pkt. 4 („Eksperyment powinien być tak przeprowadzony, aby uniknąć wszelkich niepotrzebnych cierpień i uszczerbków, fizycznych i psychicznych”) i 5 („Eksperyment nie może być przeprowadzony, jeśli z góry istnieje podstawa do przypuszczenia, że może nastąpić śmierć lub kalectwo, z wyjątkiem może tych eksperymentów, które eksperymentator przeprowadza także na sobie") KN pozwalały na pewien poziom takiego zagrożenia. 
Nie była to legalna egzekucja przeprowadzona zgodnie z prawem wojennym i regułami wojennymi, lecz zbrodniczy eksperyment medyczny, w czasie którego zadano więźniom rany jedynie w celu ustalenia skuteczności zatrutych pocisków jako środka uśmiercającego ${ }^{54}$.

Nie odniósł się jednak do kwestii ewentualnych obietnic rezygnacji z wykonania kary śmierci w zamian za udział w eksperymencie. Dostrzec to można w stanowisku ATW nr 1 zajętym wobec twierdzenia obrońcy K. Gebhardta, który - dostrzegając zapewne słabość argumentacji opartej na zgodzie więźniarek z Ravensbrück wobec faktu, że operowano je wbrew wyraźnym sprzeciwom - ostatecznie przyjął, że w ogóle nie jest potrzebne ustalenie istnienia owej zgody, choćby w postaci zgody hipotetycznej, ponieważ poddanie się eksperymentom leżało w interesie uczestniczek jako jedyna droga uniknięcia śmierci5 ${ }^{55}$. W kwestii tej ATW nr 1 stwierdził jedynie, że ofiary tych eksperymentów zostały „uwięzione w Ravensbrück bez zachowania choćby pozorów procesu” i „ten fakt mógł być Gebhardtowi znany, gdyby bodaj pobieżnie zbadał ich sytuację prawną" ${ }^{56}$. ATW nr 1 nie wypowiedział się też w kwestii dopuszczalności eksperymentowania na populacji więziennej. Oskarżenie zasadniczo rozstrzygało ją pozytywne pod warunkiem zgody uczestnika ${ }^{57}$. Obrona opowiadała się za dopuszczalnością pominięcia zgody, a rozbieżności zarysowały się co do zdolności więźnia do jej wyrażenia. Pozytywnie zdolność tę oceniał obrońca S. Ruffa ${ }^{58}$, ale już obrońca K. Brandta podawał w wątpliwość możliwość uzyskania rzeczywistej zgody, podnosząc, że więzień funkcjonuje $\mathrm{w}$ warunkach pewnego rodzaju przymusu, że od udziału w eksperymencie oczekuje poprawy swojej sytuacji, a obawia się jej pogorszenia w razie odmowy. Miało to wszakże przesądzać o dopuszczalności eksperymentu z pominięciem wymogu zgody w razie wspomnianej już wyższej konieczności, szczególnie że skazany jest ciężarem dla

54 Tamże, s. 246-247.

55 Zob. tamże, s. 12-13. Obrona pominęła tu fakt, że wszystkie operowane więźniarki miały być rozstrzelane w celu zatarcia śladów eksperymentów, zob. W. Półtawska, Operacje..., s. 88-89.

56 Tamże, s. 224.

57 Podobnie zob. Extracts from the testimony of prosecution expert witness dr. Andrew C. Ivy, w: Trials I, s. 995-1001 i II, s. 60.

58 Zob. Extract from the closing brief for defendant Ruff, w: Trials I, s. 990-992. 
społeczeństwa ${ }^{59}$. Na usprawiedliwienie zarzuconych oskarżonym eksperymentów podnoszono nawet to, że stanowiły one substytut kary orzeczonej wcześniej wobec uczestników ${ }^{60}$. Stanowisko ATW nr 1 w przedstawionej kwestii uznać należy za niejednoznaczne ${ }^{61}$, chociaż w literaturze z pkt $1 \mathrm{KN}$ wywodzony jest zakaz eksperymentowania na osobie pozbawionej wolności ${ }^{62}$ albo wątpliwość co do dopuszczalności takiej praktyki ${ }^{63}$.

\section{Eksperyment badawczy w ponorymberskim międzynarodowym prawie karnym}

Do prawnokarnej oceny eksperymentu badawczego w wyroku ATW nr 1 wyraźnie nawiązuje włączenie eksperymentu badawczego do opisu zbrodni wojennych $\mathrm{w}$ ponorymberskim międzynarodowym prawie konfliktów zbrojnych. W konwencjach genewskich eksperymenty z udziałem osób chronionych tym prawem, określone jako „biologiczne”, zostały wymienione wśród „ciężkich naruszeń" (grave breaches), które wymagają kryminalizacji przez państwa-strony ${ }^{64}$. Protokół dodatkowy do konwen-

59 Zob. Final plea for defendant Karl Brandt by dr. Servatius, w: Trials II, s. 128-129; Extracts from the closing brief for defendant Karl Brandt, s. 984-986, 989.

60 Zob. Extracts from the closing brief for defendant Karl Brandt, s. 986, 989; Extract from the testimony of defendant Mrugowsky, s. 56, 57; Extracts from the closing brief against defendant Mrugowsky, w: Trials I, s. 632.

61 Zob. Zob. zwłaszcza wyrok ATW nr 1 s. 227, 271, 273-274; I. Kiriakaki, Das Humanexperiment als völkerstrafrechtliches Verbrechen - Vom Nürnberger Kodex zum Rom-Statut für einen Internationalen Strafgerichtshof, Zeitschrift für die Gesamte Strafrechtswissenschaft 2006, nr 1, s. 236-237.

${ }_{62}$ Zob. Y. Ternon, Genèse et sens du Code du Nuremberg, w: De Nuremberg à la loi Huriet. Essais thérapeutiques et recherche médicale, red. S. Abtroun, Paris 2001, s. 99, 102.

63 Zob. M.C. Bassiouni, T.G. Baffes, J.T. Evrard, An Appraisal..., s. 1641.

64 Zob. art. 49-50 konwencji genewskiej z dnia 12 sierpnia 1949 r. o polepszeniu losu rannych i chorych w armiach czynnych (UNTS1950, t.75, s. 31, Dz. U.z1956 r. Nr38, poz.171, z późn. zm., dalej: I k.g.), art. 50-51 konwencji genewskiej z dnia 12 sierpnia 1949 r. o polepszeniu losu rannych, chorych i rozbitków sił zbrojnych na morzu (UNTS 1950, t. 75, s. 85, Dz. U. z 1956 r. Nr 38, poz. 171, z późn. zm. dalej: II k.g.), art. 129-130 konwencji genewskiej z dnia 12 sierpnia 1949 r. o traktowaniu jeńców wojennych (UNTS 1950, t. 75, s. 135, Dz. U. z 1956 r. Nr 38, poz. 171, z późn. zm.; dalej: III k.g.), art. 146-147 konwencji genewskiej z dnia 12 sierpnia 1949 r. o ochronie osób cywilnych podczas wojny (UNTS 1950, t. 75, s. 287, Dz. U. z 1956 r. Nr 38, poz. 171, z późn. zm.; dalej: IV k.g.). Zob. też 
cji genewskich dotyczący ochrony ofiar międzynarodowych konfliktów zbrojnych z 8 czerwca 1977 r. tak samo kwalifikuje „eksperyment medyczny lub naukowy”, który „poważnie zagraża fizycznemu lub psychicznemu zdrowiu lub integralności" osoby ${ }^{65}$. Badawcze wykorzystanie ofiar wojny objęte zostało również opisem zbrodni wojennych poddanych jurysdykcji MTK $^{66}$. Statut MTK nie wprowadził tu istotnych zmian w zakresie kryminalizacji, chociaż poszerzył go o konflikty zbrojne o charakterze niemiędzynarodowym. Eksperyment określony jako „biologiczny” stanowi przejaw „tortur lub nieludzkiego traktowania” kryminalizowanych jako ciężkie naruszenia (grave breaches) konwencji genewskich z 1949 r. (art. 8 ust. 2 lit. a pkt ii Statutu MTK). Wśród „innych poważnych naruszeń (serious violations) praw i zwyczajów w zakresie prawa międzynarodowego" w konfliktach zbrojnych o charakterze międzynarodowym (art. 8 ust. 2 lit. b x Statutu MTK) i niemiędzynarodowym (art. 8 ust. 2 lit. e xi Statutu MTK) wymienione zostało natomiast poddawanie osób będących we władzy strony przeciwnej (albo innej strony konfliktu, jeśli ma on charakter niemiędzynarodowy) okaleczeniu fizycznemu lub jakiegokolwiek rodzaju eksperymentom medycznym lub naukowym, które nie znajdują uzasadnienia w medycznym, dentystycznym lub szpitalnym leczeniu osoby

art. 12 I k.g. i art. 12 II k.g., które zakazują poddawania osób objętych ochroną konwencyjną „eksperymentom biologicznym”; art. 13 III k.g. zakazujący poddania jeńca wojennego „eksperymentom medycznym lub naukowym jakiegokolwiek rodzaju, które nie znajdują uzasadnienia w medycznym, dentystycznym lub szpitalnym leczeniu tego jeńca i nie są przeprowadzane w jego interesie" i art. 32 IV k.g. zakazujący "eksperymentów medycznych lub naukowych, które nie są konieczne dla leczenia osoby podlegającej ochronie".

65 UNTS 1986, t. 1125, s. 3, Dz. U. z 1992 Nr 41, poz. 175, dalej: Protokół I. Zob. art. 11 ust 4 i art. 85 Protokołu I. W innym miejscu Protokół I zabrania poddawania chronionych nim osób „jakiemukolwiek postępowaniu medycznemu, które nie jest uzasadnione stanem zdrowia osoby zainteresowanej i nie jest zgodne z powszechnie uznanymi standardami medycznymi, jakie miałyby zastosowanie w podobnych warunkach medycznych do własnych obywateli strony przeprowadzającej to postępowanie, którzy nie są w jakikolwiek sposób pozbawieni wolności" (art. 11 ust. 1), a w szczególności przeprowadzania na osobach chronionych, nawet za ich zgodą, eksperymentów medycznych lub naukowych, „chyba że działania takie są usprawiedliwione w myśl warunków przewidzianych w ustępie 1" (art. 11 ust. 2 lit. b).

${ }^{66}$ Zgodnie z art. 5 Statutu Rzymskiego Statutu Międzynarodowego Trybunału Karnego z dnia 17 lipca 1998 r. (UNTS 2004, t. 2187, s. 3; Dz. U. z 2003 r. Nr 78, poz. 708) jurysdykcja MTK jest ograniczona do najpoważniejszych przestępstw dotyczących wspólnoty międzynarodowej jako całości. 
zainteresowanej ani nie są przeprowadzane $\mathrm{w}$ jej interesie i powodują śmierć lub poważnie zagrażają zdrowiu takiej osoby lub osób ${ }^{67}$.

W ślad za przedmiotowym zakresem „procesu lekarzy” ponorymberskie prawo konfliktów zbrojnych uznaje za zbrodnię wojenną wyłącznie eksperyment badawczy. Kryminalizacja nie obejmuje eksperymentalnych interwencji medycznych realizujących cel leczniczy wobec uczestnika ${ }^{68}$. Wynika to z wyraźnych wyłączeń ${ }^{69}$ bądź z określenia eksperymentu jako „biologiczny”70. W odróżnieniu natomiast od wyroku ATW nr 1 ochrona ofiar wojny przed wykorzystaniem badawczym ma w prawie ponorymberskim charakter bezwzględny, ponieważ nie jest zależna od zgody potencjalnego uczestnika eksperymentu ${ }^{71}$. Można tu nawet dostrzec konsekwentne odczytanie warunków skuteczności zgody określonych w pkt. $1 \mathrm{KN}$ w sytuacji pozbawienia lub ograniczenia wolności ${ }^{72}$, którego zabrakło w omawianym wyroku. Zarazem jednak w niektórych opisach zbrodni wojennych eksperyment badawczy ujęty został jako skutkowa

67 Trzykrotne uwzględnienie eksperymentu wśrod zbrodni wojennych w Statucie MTK wynika ze zróżnicowanego zakresu ochrony w zależności od źródła dotychczasowego zakazu w prawie międzynarodowym i rodzaju konfliktu zbrojnego (zob. W.A. Schabas, The International Criminal Court: A Commentary on the Rome Statute, New York 2010, s. 195-199, 202, 213; S. Mehring, Medical war crimes, Max Plank Yearbook of United Nations Law, 2011, t. 15, s. 246-247; L. Moir, Conduct of Hostilities - War Crimes, w: The Legal..., s. 510-514).

68 Zob. M. Klamberg (red.), w: Commentary on the Law of the International Criminal Court, Brussels 2007, s. 69, 91-92, 144; S. Negri, Unethical Human Experimentation in Developing Countries and International Criminal Law: Old Wine in New Bottles?, International Criminal Law Review 2017, nr 6, s. 1043.

69 Zob. art. 13 III k.g., art. 32 IV k.g., art. 11 Protokołu I, art. 8 ust. 2 lit. b x i art. 8 ust. 2 lit. e xi Statutu MTK.

70 Zob. The Geneva Conventions of 12 August 1949. Commentary, red. J. S. Pictet, t. 1, Geneva 1952, s. 139; I. Kiriakaki, Das Humanexperiment..., s. 243; Elements of Crimes, Official Records of the Review Conference of the Rome Statute of the International Criminal Court, Kampala, 31 May - 11 June 2010 (International Criminal Court publication, RC/11), Article 8 (2) (a) (ii)-3, pkt 3.

71 Zob. I. Kiriakaki, Das Humanexperiment..., s. 243; L. Moir, Conduct..., s. 512, 514; M. Klamberg (red.), w: Commentary..., s. 69, 91, 144; S. Mehring, Medical..., s. 243.

72 Zob. A. Wnukiewicz-Kozłowska, Eksperyment medyczny na organizmie ludzkim w prawie międzynarodowym i europejskim, Warszawa 2004, s. 86; Y. Sandoz, w: Commentary on the Additional Protocols of 8 June 1977 to the Geneva Conventions of 12 August 1949, red. Y. Sandoz, Ch. Swinarski, B. Zimmermann, Geneva 1987, s. 156-157. 
odmiana przestępstwa ${ }^{73}$, co zdaje się ograniczać zakres odpowiedzialności karnej w porównaniu z wyrokiem ATW nr 1.

Wskazane przepisy ograniczają ochronę przed wykorzystaniem badawczym do osób uznanych za ofiary wojny ${ }^{74}$. Jest to charakterystyczne dla zbrodni wojennych, których istota zakłada realizację zabronionych czynności sprawczych w okolicznościach konfliktu zbrojnego, chociaż nie musi być to powiązanie przyczynowe ${ }^{75}$. Dlatego warto zaznaczyć, że równolegle do kształtowania się ponorymberskiego prawa humanitarnego podejmowane były próby uznania eksperymentu badawczego za czynność sprawczą przestępstw międzynarodowych możliwych do popełnienia także w czasie pokoju. Dostrzec je można jeszcze przed zakończeniem „procesu lekarzy", w pracach nad konwencją zakazującą ludobójstwa ${ }^{76}$. W jej początkowym projekcie z 6 czerwca 1947 r. wymieniono wśród czynności sprawczych tzw. ludobójstwa fizycznego, polegającego na spowodowaniu śmierci członka grupy politycznej, rasowej, narodowej, językowej lub religijnej lub uszczerbku na jego zdrowiu, lub integralności fizycznej, w zamiarze zniszczenia owej grupy lub przeszkodzenia w jej zachowaniu bądź rozwoju „eksperymenty biologiczne, dokonywane w innym celu niż leczniczy” (art. I ust. II, pkt 1 lit. c) ${ }^{77}$. Ostatecznie jednak eksperyment badawczy nie znalazł się w konwencyjnym opisie ludobójstwa ${ }^{78}$. Nie został również zali-

73 Zob. art. 11 ust. 4 Protokołu I, art. 8 ust. 2 lit. b x i lit. e xi Statutu MTK. W kwestii art. 8 ust. 2 lit. a pkt ii Statutu MTK zaznaczyć warto, że chociaż jego treść uniezależnia kryminalizację eksperymentu od ewentualnego uszczerbku na zdrowiu (zob. K. Dörmann, Elements of War Crimes under the Rome Statute of the International Criminal Court, Cambridge 2004, s. 71), to w oficjalnej wykładni tego przepisu wymaga się, aby eksperyment poważnie zagroził fizycznemu lub psychicznemu zdrowiu lub integralności osoby albo osób pokrzywdzonych (zob. Elements of Crimes..., art. 8 ust. 2 lit. a ii-3, pkt 2).

74 Zob. W.A. Schabas, The International..., s. 202, 201.

75 Zob. I. Marchuk, The Fundamental Concept of Crime in International Criminal Law, Berlin-Heidelberg 2014, s. 95; S. Negri, Unethical..., s. 1043; S. Mehring, Medical..., s. 240.

76 Zob. M.C. Bassiouni, T.G. Baffes, J.T. Evrard, An Appraisal..., s. 1661.

77 Convention on the Prevention and Punishment of the Crime of Genocide. Secretariat Draft. First Draft of the Genocide Convention, Prepared by the UN Secretariat, [May] 1947 [UN Doc. E/447], http://www.preventgenocide.org. Nt. podobnych propozycji w pracach nad konwencją zob. Ściganie i karanie sprawców zbrodni wojennych i zbrodni przeciwko ludzkości (Wybór dokumentów), red. C. Pilichowski, Warszawa 1978, s. 284, 295.

78 Zob. art. II Konwencji w sprawie zapobiegania i karania zbrodni ludobójstwa z dnia 9 grudnia 1948 r. (UNTS 1951, t. 78, s. 277, Dz. U. z 1952 Nr 2, poz. 9 z późn. zm.). Opis ten powtarza art. 6 Statutu MTK. 
czony do czynności sprawczych zbrodni przeciwko ludzkości zamieszczonym w art. 7 Statutu MTK. Nie jest oczywiście wykluczone zastosowanie tej ostatniej kwalifikacji do szczególnie poważnych przypadków bezprawnych eksperymentów badawczych. Byłaby ona jednak znacznie bardziej utrudniona niż w przypadku zbrodni wojennych. Oceniane interwencje medyczne musiałyby spowodować skutek uwzględniony w opisie przestępstw przeciwko ludzkości (np. zabójstwo - art. 7 ust. 1 lit. a Statutu MTK) lub cechować się poziomem dolegliwości tortur wymienionych $\mathrm{w}$ art. 7 ust. 1 lit. $\mathrm{f}$ w zw. z ust. 2 lit. e Statutu MTK, lub mieć postać nieludzkich czynów o charakterze podobnym do wymienionych $\mathrm{z}$ nazwy w art. 7 ust. 1 Statutu MTK (m.in. zabójstwo, eksterminacja, tortury), ",celowo powodujących ogromne cierpienie lub poważne uszkodzenie ciała albo zdrowia psychicznego lub fizycznego" (art. 7 ust. 1 lit. k Statutu MTK) ${ }^{79}$. Ponadto z uwagi na właściwą dla przestępstw przeciwko ludzkości okoliczność popełnienia w ramach „rozległego lub systematycznego, świadomego ataku skierowanego przeciwko ludności cywilnej" ${ }^{80}$, kwalifikacja ta byłaby możliwa do zastosowania tylko do zorganizowanych programów badawczych wykraczających poza indywidualne przypadki eksperymentowania na człowieku ${ }^{81}$. Nie jest natomiast wykluczona prawodawcza ewolucja konstrukcji przestępstw przeciwko ludzkości zmierzająca do objęcia nią najbardziej drastycznych form eksperymentowania na człowieku, szczególne że z opisu czynności sprawczych w art. 7 ust. 1 lit. k Statutu MTK wywodzi się wniosek, że ich katalogu nie da się definitywnie zamknąć i wymaga on ciągłej weryfikacji na płaszczyźnie de lege ferenda ${ }^{82}$. Wśród kierunków ewentualnego poszerzenia tego katalogu doktryna wymienia medyczne interwencje będące zamachem na ludzki genom, w szczególności klonowanie człowieka lub tworzenie istot ludzko-zwierzęcych ${ }^{83}$.

79 Zob. S. Negri, Unethical..., s. 1044.

80 Zob. art. 7 ust. 2 lit. a Statutu MTK; I. Fouchard, w: M. Delmas-Marty i in., Le crime..., s. 28-31, 37-40; J. Nilsson, w: Commentary..., red. M. Klamberg, s. 31-35; I. Marchuk, The Fundamental..., s. 96, 104.

81 Zob. S. Negri, Unethical, s. 1044-1046.

82 Zob. I. Fouchard, w: M. Delmas-Marty i in., Le crime..., s. 10, 37; Commentary..., red. M. Klamberg, s. 60.

83 Szerzej zob. M. Delmas-Marty, Le crime contre l'humanité les droits de l'homme et irréductible humain, Revue de Science Criminelle et de Droit Pénal Comparé 1994, nr 3, s. 488-490; C.M. Romeo Casabona, Penal Limits of Gene Manipulation, w: The Legal and Ethical Aspects related to the Project of the Human Genome, red. B. Pulmann, C. Romeo Casabona, Città 
Jeszcze dalej idące próby uniezależnienia jego kryminalizacji od sytuacji wojny podjęło na przełomie lat 70. i 80. XX w. Międzynarodowe Stowarzyszenie Prawa Karnego. Po raz pierwszy nastąpiło to w projekcie Międzynarodowego kodeksu karnego z 1979 r. ${ }^{84}$, gdzie obok uznania eksperymentu medycznego za zbrodnię wojenną ${ }^{85}$ zaproponowano jego odrębną kryminalizację bez związku z konfliktem zbrojnym, a nawet z ludobójstwem i przestępstwami przeciwko ludzkości. Miało to być przestępstwo przeciwko podstawowym prawom człowieka ${ }^{86}$. Proponowany zakaz ograniczał się jednak do eksperymentów przeprowadzanych jako element polityki państwa lub przez osobę reprezentującą władzę państwową oraz niereagowania przez nią na takie interwencje. W jeszcze większym stopniu ślady wyroku ATW nr 1 dostrzec można w kolejnej inicjatywie Międzynarodowego Stowarzyszenia Prawa Karnego, zmierzającej do poszerzenia kryminalizacji eksperymentu badawczego, jaką był opublikowany w 1980 r. Projekt konwencji o zapobieganiu i karaniu nielegalnych eksperymentów na człowieku ${ }^{87}$. Uznano $\mathrm{w}$ nim nielegalny eksperyment na człowieku ${ }^{88}$

del Vaticano 1995, s. 90-93; B. Mathieu, Force et faiblesse des droits fondamenteaux comme instruments du droit de la bioéthique: le principe de dignité et les interventions sur le génome humain, Revue du Droit Publique 1999, nr 1, s. 107; L. Neyret, w: M. Delmas-Marty i in., Le crime..., s. 88-97.

84 Zob. Projet de Code Pénal International, Revue Internationale de Droit Pénal (dalej: RIDP) 1981, nr 1-2, s. 99-236 (dalej: projekt m.k.k.). W 1980 r. został przedstawiony na VI Kongresie Narodów Zjednoczonych w Karakas, gdzie uczyniono go przedmiotem debaty bez podejmowania prac prawodawczych, zob. M.C. Bassiouni, A Draft International Criminal Code and Draft Statute for an International Criminal Tribunal, Dordrecht 1987, s. 10.

85 Zob. art. II.2.3 i 4.2 projektu m.k.k., nawiązujący do art. 11 ust. 2 Protokołu I.

86 Zob. M.C. Bassiouni, A Draft..., s. 41, 43-44. Jego opis był następujący: „art. IX § 1. Bezprawne eksperymenty medyczne. Przestępstwo bezprawnego eksperymentu medycznego polega na spowodowaniu jakichkolwiek fizycznych i/lub psychicznych zmian za pomocą operacji chirurgicznych lub podania substancji w iniekcji, do spożycia lub wdychania, przez lub z inicjatywy przedstawiciela władzy publicznej lub w wyniku czynu, za który przedstawiciel władzy publicznej ponosi odpowiedzialność, jeśli osoba poddana takiemu eksperymentowi nie udzieliła zgody określonej w paragrafie 2". Zgodę uznano za udzieloną tylko wtedy, gdy dana osoba ma „zdolność wyrażenia zgody i udzieliła jej swobodnie, po uzyskaniu pełnej informacji na temat rodzaju eksperymentu i jego możliwych konsekwencji" (§ 2.1), przewidując też prawo do cofnięcia jej w każdym czasie (§ 2.2).

87 Projet de convention pour la prévention et la répression des expériences illégales sur l'homme. Texte du projet et commentaires, RIDP 1980, nr 3-4, s. 359-385 (wersja angielska s. 419-443).

88 Spod jego zakresu wyraźnie wyłączono "terapię eksperymentalną stosowaną w warunkach krańcowej konieczności" (art. 3.3). 
za zbrodnię przeciwko ludzkości podlegającą prawu międzynarodowemu (art. 2), niezależnie od osoby sprawcy ${ }^{89}$. Oznaczało to nałożenie na państwa-strony obowiązku kryminalizacji ${ }^{90}$ oraz obowiązków o charakterze karnoprocesowym $^{91}$. Zbrodnia nielegalnego eksperymentu występowała w sześciu odmianach. Pierwsza z nich obejmowała eksperyment $\mathrm{z}$ udziałem osób chronionych prawem genewskim (art. 3.1 lit. a). Druga polegała na wykorzystaniu go jako przejawu wrogiej dyskryminacji z powodu przynależności narodowej, etnicznej, rasowej, religijnej, językowej, społecznej lub politycznej (art. 3.1 lit. b). W obydwu przypadkach bezprawność czynu nie mogła być wyłączona przez zgodę uczestnika ${ }^{92}$, ochronie prawa do samostanowienia zaś służyć miały 3 kolejne zakazy karne. Pierwszy z nich obejmował eksperyment na osobie, która jest zdolna do wyrażenia świadomej zgody, ale jej nie udzieliła (art. 3.1 lit. d). Pojęcie świadomej zgody zostało zdefiniowane w sposób nawiązujący do stylistyki pkt $1 \mathrm{KN}$. Przyjęto, że jest to „zgoda udzielona przez osobę, która ma świadomość i zrozumienie problemu, wystarczające, aby podjąć świadomą decyzję". Miało to oznaczać, że

przed przyjęciem zgody od osoby mającej uczestniczyć w eksperymencie, zapoznano ją z rodzajem, czasem trwania i celem eksperymentu, metodą, za pomocą której ma być on przeprowadzony, wszelkimi uciążliwościami i ryzykiem, których należy się rozsądnie spodziewać, i skutkami oraz konsekwencjami dla zdrowia fizycznego i psychicznego tej osoby, które mogą wyniknąć z jej udziału w eksperymencie (art. 1.2 zd. 1-2)

oraz że osoba ta miała

zdolność dokonania wolnego wyboru, nie będąc pod jakimkolwiek wpływem siły, oszustwa, podstępu, przemocy, zastraszenia, trudnej sytuacji ekonomicznej lub wszelkiej presji, wymuszenia, zachęt materialnych lub innych (art. 1.2 zd. 3).

Projekt konwencji wyodrębniał też przestępstwo eksperymentu z udziałem osoby niezdolnej do wyrażenia świadomej zgody, chyba że zostały kumulatywnie spełnione następujące warunki: uczestnik w żaden sposób

\footnotetext{
89 Zob. komentarz do art. 1, Projet de convention..., s. 365.

90 Zob. art. 5.3 zd. 1, komentarz do art. 5, Projet de convention..., s. 377.

91 Zob. art. 5.2, art. 5.5-5.14.

92 Komentarz do art. 3, Projet de convention..., s. 368.
} 
nie wyraził sprzeciwu, świadomej zgody udzielił jego opiekun, jeśli został ustanowiony, istnieje konieczność naukowa przeprowadzenia eksperymentu na osobach niezdolnych do udzielenia zgody, rodzaj eksperymentu i przewidywane korzyści dotyczą wyłącznie tej szczególnej kategorii osób, a eksperyment uzyskał zezwolenie określonego ustawą organu (art. 3.1 lit. f pkt 1-4), oraz $\mathrm{z}$ udziałem jakiejkolwiek osoby znajdującej się w warunkach pozbawienia wolności lub więzienia (art. 3.1 lit. c). Bezwzględny charakter tego ostatniego zakazu jednoznacznie rozstrzygał to, co w wyroku ATW nr 1 pozostawało kwestią otwartą. Projektodawcy uznali go za konsekwencję warunków skuteczności zgody, w których zamieszczono wyraźną klauzulę o treści: „Osoby, które znajdują się w sytuacji pozbawienia wolności lub uwięzienia są uznawane za niezdolne do dokonania wolnego wyboru" (art. 1.2 zd. 4). Ślady Kodeksu norymberskiego wyraźne są również w minimalnych normach legalności eksperymentu niezależnych od warunku zgody, których naruszenie również miało być odrębnie kryminalizowane (art. 3.1 lit. e Projektu konwencji) ${ }^{93}$.

\section{Zakończenie}

Niezależnie od tego, jak postrzegać międzynarodowy charakter „procesu lekarzy" przed ATW nr 1, nie ulega wątpliwości ponadnarodowe, a wręcz uniwersalne znaczenie standardów eksperymentu w medycynie przyjętych za podstawę rozstrzygnięcia tej sprawy, i to nie tylko w wymiarze ogólnoprawnym, ale i ściśle prawnokarnym. Chociaż przed omawianym procesem kwestia odpowiedzialności karnej za badawcze wykorzystanie człowieka była podejmowana, to niewątpliwie zapoczątkował on - wraz z wyrokiem MTW - postrzeganie eksperymentów badawczych jako sposobu popełnienia najpoważniejszych zbrodni, godzących zarówno w fundamentalne dobra uczestników, jak i w najcenniejsze wartości o charakterze zbiorowym.

93 Zaliczono do nich m.in.: konieczność odpowiedniego zaplanowania eksperymentu, warunek, aby ryzyko wystąpienia szkody zostało oszacowane naukowo i aby nie było powodów, by przypuszczać, że z eksperymentu może wyniknąć śmierć, uszczerbek powodujący kalectwo, poważne lub nieodwracalne szkody fizyczne lub psychiczne, oraz uzasadnienie przewidywanego ryzyka w humanitarnym znaczeniu eksperymentu (art. 1.3 Projektu konwencji). 
Znalazło ono wyraźne odzwierciedlenie w ponorymberskim prawie karnym, chociaż ograniczone tylko do ochrony ofiar konfliktów zbrojnych.

$\mathrm{W}$ „procesie lekarzy" oraz kończącym go wyroku podjęto też istotne problemy wyłączenia bezprawności eksperymentu badawczego o kluczowym znaczeniu dla odpowiedzialności karnej za taką interwencję niezależnie od tego, czy zostanie ona zakwalifikowana jako zbrodnia wojenna lub przeciwko ludzkości, czy też jako przestępstwo przeciwko życiu lub zdrowiu. Szczególnie godne podkreślenia jest to, że wyrok ATW nr 1 wykazał niestosowalność do eksperymentu badawczego „klasycznych" instytucji prawa karnego wyłączających bezprawność, opartych na rachunku opłacalności, i nadał znaczenie uniwersalne poszanowaniu prawa do samostanowienia i prymatowi ludzkiej godności nad interesem zbiorowym. Odniesiono się w nim też do doniosłego problemu warunków skuteczności zgody, który z perspektywy prawnokarnej do dziś ma w pewnej mierze charakter otwarty. $W$ tej kwestii wyrok ATW nr 1 niewątpliwie przyczynił się do utrwalenia stanowiska, że zgoda dotknięta istotnymi wadami musi być traktowana $w$ prawnokarnych ocenach eksperymentu badawczego jako tożsama z brakiem zgody.

$\mathrm{Z}$ uwagi na to, że ATW nr 1 oparł się na ustaleniach minimalnych, wystarczających do potwierdzenia zarzutów oskarżenia - minimalnych nawet na tle zasad Kodeku norymberskiego - omawiany wyrok niewątpliwie pozostawia kilka niepokojących pytań, zwłaszcza w kwestii eksperymentowania na osobie pozbawionej wolności oraz granic dopuszczalnego narażenia uczestnika eksperymentu medycznego na niebezpieczeństwo dla zdrowia. O ile pierwsze z nich znalazło - przynajmniej częściowe - rozstrzygnięcie $\mathrm{w}$ ponorymberskim prawie konfliktów zbrojnych oraz późniejszych standardach biomedycznych, o tyle drugie w zasadzie nie zostało rozstrzygnięte optymalnie do dziśs ${ }^{94}$.

94 Szerzej zob. M. Gałązka, Prawnokarne..., s. 764-766. 


\section{Bibliografia}

Amiel P., Des cobayes et des hommes. Expérimentation sur l'être humain et justice, Paris 2011.

Annas G.J., Glantz L.H., Katz B.F., Informed Consent to Human Experimentation: The Subject's Dilemma, Cambridge, Massachusetts 1977.

Bassiouni M.C., Baffes T.G., Evrard J.T., An Appraisal of Human Experimentation in International Law and Practice: the Need for International Regulation of Human Experimentation, Journal Criminal Law and Criminology 1981, t. 72, nr 4.

Bassiouni M.C., A Draft International Criminal Code and Draft Statute for an International Criminal Tribunal, Dordrecht 1987.

Commentary on the Additional Protocols of 8 June 1977 to the Geneva Conventions of 12 August 1949, eds. Y. Sandoz, Ch. Swinarski, B. Zimmermann, Geneva 1987.

Commentary on the Law of the International Criminal Court, red. M. Klamberg, Brussels 2007.

Cyprian T., Sawicki J., Nieznana Norymberga. Dwanaście procesów norymberskich, Warszawa 1965.

Delmas-Marty M. i in., Le crime contre l'humanité, Paris 2018.

Dörmann K., Elements of War Crimes under the Rome Statute of the International Criminal Court, Cambridge 2004.

Gałązka M., Prawnokarne granice nowatorskiej interwencji medycznej, Lublin 2019.

Ghooi R.B., The Nuremberg Code - A critique, Perspectives in Clinical Research 2011, nr 2.

Kielanowski T., Odpowiedzialność uczonych. Dylemat współczesnej nauki, Warszawa 1970.

Kiriakaki I., Das Humanexperiment als völkerstrafrechtliches Verbrechen - Vom Nürnberger Kodex zum Rom-Statut für einen Internationalen Strafgerichtshof, Zeitschrift für die Gesamte Strafrechtswissenschaft 2006, nr 1.

Kulesza W., Crimen laesae iustitiae. Odpowiedzialność karna sędziów i prokuratorów za zbrodnie sadowe wedtug prawa norymberskiego, niemieckiego, austriackiego i polskiego, Łódź 2013.

Lifton R.J., Ärzte im Dritten Reich, tłum. A. Lösch i in., Stuttgart 1988.

Maogoto J., The Work of National Military Tribunals under Council Control Law 10, w: The Legal Regime of the International Criminal Court: Essays in Honour of Professor Igor Blishchenko, eds. J. Doria, H.P. Gasser, M.C. Bassiouni, Leiden-Boston 2009.

Marchuk I., The Fundamental Concept of Crime in International Criminal Law, Berlin-Heidelberg 2014.

Mehring S., Medical war crimes, Max Plank Yearbook of United Nations Law, 2011, t. 15. 
Mitscherlich A., Mielke F., Nieludzka medycyna. Dokumenty procesu norymberskiego przeciwko lekarzom, tłum. A. Bukowczyk, Warszawa 1963.

Moir L., Conduct of Hostilities - War Crimes, w: The Legal Regime of the International Criminal Court: Essays in Honour of Professor Igor Blishchenko, eds. J. Doria, H.P. Gasser, M.C. Bassiouni, Leiden-Boston 2009.

Moreno J.D., Undue risk. Secret State Experiments on Humans, New York 1999.

Negri S., Unethical Human Experimentation in Developing Countries and International Criminal Law: Old Wine in New Bottles?, International Criminal Law Review 2017, nr 6.

Półtawska W., Operacje doświadczalne w obozie koncentracyjnym Ravensbrück, w: Okupacja i medycyna. Drugi wybór artykułów z "Przeglądu Lekarskiego - Oświęcim” z lat 1961-1973, wybór zespół red. „Przeglądu Lekarskiego - Oświęcim”, Warszawa 1975.

Sass H.-M., Ambiguities In Judging Cruel Human Experimentation: Arbitrary American Responses to German and Japanese Experiments, Eubios Journal of Asian and International Bioethics 2003, Vol. 3.

Schabas W.A., The International Criminal Court: A Commentary on the Rome Statute, New York 2010.

Shuster E., Fifty years later: the significance of the Nuremberg Code, The New English Journal of Medicine 1997, t. 337, nr 20.

Sterkowicz S., Lekarze-mordercy spod znaku swastyki, Torun 1999.

Sterkowicz S., Nieludzka medycyna. Lekarze w stużbie nazizmu, Warszawa 2007.

Ternon Y., Genèse et sens du Code du Nuremberg, w: De Nuremberg à la loi Huriet. Essais thérapeutiques et recherche médicale, red. S. Abtroun, Paris 2001.

Wnukiewicz-Kozłowska A., Eksperyment medyczny na organizmie ludzkim w prawie międzynarodowym i europejskim, Warszawa 2004.

\section{Streszczenie}

Artykuł poddaje analizie znaczenie tzw. procesu lekarzy przed Amerykańskim Trybunałem Wojskowym nr 1 w Norymberdze z perspektywy prawa karnego. Przedmiotem tego procesu, zakończonego wyrokiem z 19 i 20 sierpnia 1947 r., była odpowiedzialność karna sprawców eksperymentów prowadzonych w hitlerowskich obozach koncentracyjnych. Przyjęta w wyroku ATW nr 1 kwalifikacja prawna uznała te praktyki za sposób popełnienia zbrodni wojennych i zbrodni przeciwko ludzkości. Znalazła ona kontynuację w prawie konfliktów zbrojnych, chociaż nie powiodły się próby szerszej kryminalizacji w prawie międzynarodowym badawczego wykorzystania człowieka. Proces norymberski ukazał zarazem nieadekwatność klasycznych instytucji wyłączających bezprawność czynu do eksperymentu badawczego, dając podstawy dla wykształcenia się szczególnych 
warunków dopuszczalności badań medycznych opartych na zasadzie prymatu człowieka nad interesami zbiorowymi.

Słowa kluczowe: eksperyment medyczny, Kodeks norymberski, międzynarodowe prawo karne, medyczne prawo karne, stan wyższej konieczności

\section{THE SIGNIFICANCE OF “THE MEDICAL CASE” BEFORE THE UNITED STATES MILITARY TRIBUNAL I OF NUREMBERG FOR THE CRIMINAL LAW ASSESSMENT OF RESEARCH EXPERIMENTS}

\section{Sum mary}

The article analyses the significance of the so-called "Medical Case" before the United States Military Tribunal I in Nuremberg from the perspective of criminal law. The object of this trial, which resulted with a judgment of 19th and 20th August 1947, was the criminal liability of perpetrators of experiments conducted in Nazi concentration camps. The legal qualification adopted in this judgment recognized these practices as a way of committing war crimes and crimes against humanity. It has found continuation in the law of armed conflicts, although attempts to criminalize in international law the research exploitation of a human at a more extensive scope failed. The Nuremberg trial also demonstrated the inadequacy of classical institutions excluding the unlawfulness of an act to the research experiment. At the same time, it provided a basis for the development of specific conditions for the admissibility of medical research, grounded on the principle of primacy of the human being over collective interests.

Key words: human experimentation, Nuremberg Code, international criminal law, medical criminal law, state of necessity

\section{ЗНАЧЕНИЕ „СУДЕБНОГО РАЗБИРАТЕЛЬСТВА ПО ДЕЛУ ВРАЧЕЙ \\ В НЮРНБЕРГСКОМ ВОЕННОМ ТРИБУНАЛЕ США (ДЕЛО № 1) ДЛЯ УГОЛОВНО-ПРАВОВОЙ ОЦЕНКИ ИССЛЕДОВАТЕЛЬСКИХ ЭКСПЕРИМЕНТОВ}

\section{Резюме}

В статье анализируется значение так называемого «дела докторов» суда над врачами в Нюрнбергском военном трибунале США (дело № 1) с точки зрения уголовного права. Предметом этого судебного разбирательства, закончившегося приговором от 19 и 20 августа 1947 г., была уголовная 
ответственность исполнителей экспериментов, проводимых в нацистских концентрационных лагерях. Юридическая квалификация, принятая в приговоре, вынесенном Нюрнбергским военным трибуналом США (дело № 1), признала такую практику способом совершения военных преступлений и преступлений против человечности. Это нашло продолжение в праве вооруженных конфликтов, хотя попытки широко криминализировать использование человека в исследованиях в международном праве потерпели неудачу. Нюрнбергский процесс также показал неадекватность классических институтов, исключающих противоправность действия исследовательского эксперимента, обеспечивая основу для возникновения особых условий допустимости медицинских исследований, основанных на принципе приоритета человека над коллективными интересами.

Ключевые слова: медицинский эксперимент, Нюрнбергский кодекс, международное уголовное право, медицинское уголовное право, состояние необходимости 